\title{
The Effect of Open Innovation on Technology Value and Technology Transfer: A Comparative Analysis of the Automotive, Robotics, and Aviation Industries of Korea
}

\author{
Jinhyo Joseph Yun ${ }^{1, *(\mathbb{D})}$, EuiSeob Jeong ${ }^{2, *}$ YoungKyu Lee $^{3}$ and KyungHun Kim ${ }^{4}$ \\ 1 Convergence Research Center for Future Automotive Technology, Daegu Gyeongbuk Institute of Science \\ and Technology (DGIST), Daegu 42988, Korea \\ 2 Korea Institute of Science and Technology Information (KISTI), Hoegi-ro, 66 Dongdemun-gu, \\ Seoul 130-741, Korea \\ 3 Jisung International Patent Law Office, Seoul GangnamG, 06175 u TeheranRo 108Gil 11 Samho Building 3rd \\ Floor, Seoul 06175, Korea; yklee@jisungpat.co.kr \\ 4 Local Administration Development Institute (LADI), DalseuGu, YoungsanRo, 3, Daegu 42768, Korea; \\ ecokonut@naver.com \\ * Correspondence: jhyun@dgist.ac.kr (J.J.Y.); esjng@kisti.re.kr (E.J.); Tel.: +82-10-6697-8355 (J.J.Y.)
}

Received: 10 June 2018; Accepted: 12 July 2018; Published: 13 July 2018

\begin{abstract}
With the advent of the Fourth Industrial Revolution, the Korean industrial environment has been rapidly changing. As a result, several industries are facing different innovation conditions, including: the automotive industry, which is a traditional manufacturing industry in Korea; the aerospace industry, which has been vertically integrated, and has been led by a single large company-Korea Aerospace Industries—since Korea went through an economic crisis in the 1990s; and the robotics industry, which is currently emerging. This study used parameters related to patents originating from the automobile, robotics, and aerospace fields. The patents subjected to analysis were those registered in Korea from 2001 to 2014, and included those that were applied for, jointly applied for, or registered by Korean companies. This study analyzed the differences caused by the effect of open innovation in the three industries. According to our results, first, the three industries experienced different effects of open innovation. Second, when large companies controlled a given industry, open innovation either worked a little or did not work at all. According to this research result, the Korean robotics industry, which has a weak dominance of large companies, experienced a strong effect of open innovation, in that joint patent applications led to economic gains from the patents and an increase in technology transfer and technology value. The aerospace industry of Korea, which has the highest dominance of large companies, experienced a slight effect of open innovation, as the effect of joint patent application only improved the technology value. Finally, the automotive industry of Korea had an intermediate level of open innovation, between the aerospace and robotics sectors.
\end{abstract}

Keywords: open innovation; aerospace; automotive; robot; joint patent application

\section{Introduction}

The Korean industrial environment is fast changing with the advent of the Fourth Industrial Revolution [1]. Three major manufacturing industries that represent Korea are the automotive industry, which is a traditional manufacturing sector in Korea; the aviation industry, which was vertically integrated and has been led by a single large company—Korea Aerospace Industries (KAI)—since 
Korea went through an economic crisis in the 1990s; and the robotics industry, which is currently emerging [2,3].

However, these three industries have faced significantly different innovation environments. In the automobile industry, three complete vehicle companies-Hyundai Motor Company, General Motors Korea, and SsangYong Motor-are competing with other global companies, and parts companies have high-level technologies so that they can directly supply their parts to complete vehicle companies worldwide. In addition, with the advent of new automotive industry paradigms, such as self-driving cars and electric cars, many small and medium enterprises (SMEs) in this industry have made various open innovation-related efforts to secure new technologies and markets [4-6].

Korea's robotics sector has grown based on the existing industrial robotics industry, and the intelligent robotics sector, which has recently attracted much interest, is at the dawn of a new era. In addition to the existing robotics industry, which has not yet confirmed its vertical integration and dominance of large companies, various creative open innovation cases in technology, the market, and society actively occur in electronics/electrical industry; software (SW) industry; manufacturing industries, which vary a great deal; and the intelligent robotics industries [6-9].

Although the global aviation field has greatly expanded since 2010, the single governing structure of the Korean aviation sector has been firmly strengthened, and it is led by KAI. KAI's turnkey system, which has been used since 2016, has strengthened its vertical integration and threatened some local aviation parts companies, which have grown large enough to directly supply parts to global aviation companies, such as Boeing and Airbus. In addition, in the case of the highly functional unmanned aerial vehicle industry, to which the world is paying attention, the existing aviation companies, including $\mathrm{KAI}$, cannot properly address the needs of this sector. However, companies in other industries have actively entered this field.

\subsection{Research Hypothesis}

In these situations, the differences between the three major industries in Korea may lead to different effects of open innovation. This research aims to verify the following hypotheses: (1) the three industries may experience varying effects of open innovation; and (2) when large companies control a specific industry, the effect of open innovation may be weak or disappear completely.

\subsection{Research Scope and Method}

First, this research targeted patents in the automobile, robotics, and aerospace industries registered in Korea from 2000 to 2014. We analyzed the number of patents, the patents jointly applied for, the owners of patent rights, technology transfer cases, and the legal disputes of each company over patents, as well as the number of sub-International Patent Classifications (IPCs) of 7 digits (7D). Through the process of patent analyses, this research measured the width and depth of corporate open innovation, the technology transfer level of companies, and the economic and technological values of corporate technologies.

This study used the patent bibliographic data, patent registration information, patent history of administrative processes, and patent trials provided by the Korea Institute of Patent Information (www.kipris.or.kr). Based on the patents registered in Korea, we targeted automobile patents (B60), robot patents (B25J), and aviation patents (B64) registered during a 15-year period, from 2000 to 2014. These are summarized in Table 1.

As shown in Table 1, the Korean automobile industry has much larger numbers of patent applications and registrations than the Korean robotics or aerospace industry have, much like the size of the industry itself. However, even though the size of the Korean aerospace industry is not much smaller than the robotics industry, the number of patent applicants and registrations by the robotics industry of Korea is more than double that of the aerospace industry. 
Table 1. Patents of the three industries.

\begin{tabular}{ccccc}
\hline Category & B60 (Automotive) & B25J (Robot) & B64 (Aviation) & Total \\
\hline Category & 44,131 & 3896 & 1293 & 49,320 \\
53,694 & 48,061 & 4253 & 1380 & \\
60,330 & 53,941 & 4849 & 1540 & 828 \\
History of administrative processes & 305 & 426 & 97 & 1122 \\
Patent litigation & 958 & 123 & 41 & \\
\hline
\end{tabular}

Based on 'the history of administrative process', we classified the technology transfer cases as exclusive license, non-exclusive license, and transfer of right, as shown in Table 2.

Table 2. Technology transfer cases.

\begin{tabular}{cl}
\hline Category & \multicolumn{1}{c}{ Name } \\
\hline TT_1 & [Exclusive License] [Full Transfer] Transfer of Right \\
TT_2 & [Exclusive License] Request for the Registration of the Establishment of License \\
TT_3 & [Non-exclusive License] Request for the Registration of the Establishment of License \\
TT_4 & [Patent Right] [Partial Transfer] Transfer of Right \\
TT_5 & [Patent Right] [Full Transfer] Transfer of Right \\
TT_6 & [Patent Right] [Partial Transfer of Share] Transfer of Right \\
TT_7 & [Patent Right] [Full Transfer of Share] Transfer of Right \\
\hline
\end{tabular}

\section{Literature Review and Research Framework}

\subsection{Literature Review}

In the history of innovation studies, The theory of economic development [10], and capitalism, socialism, and democracy by Schumpeter have long historical links with Chesbrough's concept of open innovation in the social dimension of the learning economy [10,11].

Popularized by Chesbrough [11], open innovation refers to the simultaneous use of internal and external resources to strengthen the innovation capabilities of a firm and improve its innovation performance [12]. Diverse cooperation—collaboration among firms, universities, or research institutes-has a positive influence on innovation intensity and innovation output [13]. However, open innovation can also undermine the ability of the firm by increasing its complexity, though it may also provide the firm more flexible and creative opportunities [14,15].

We can use patents to create systematic measures of the intangibles that drive economic growth [16]. Patents that are publicly owned and frequently referenced are normally more valuable than others in an auction environment [17]. A firm's litigiousness—in other words, its high reputation for toughness on patent enforcement-significantly reduces spillovers by inventor mobility [18]. In the firm's formalized internal intellectual property value chain with a timing sequence of knowledge generation and loss, if firms in a high open innovation industry increase collaboration, such as engaging in outsourcing, litigation also increases due to the growth of the economic value of patents [19]. However, such open innovation strategies, like strategic alliances, form patent pools, and substantially and significantly decrease both the quantity and quality of patents subsequently generated by licensors and licensees that exist in the linkages between market conditions for technology and economic outcomes [20,21].

As the industrial economy changes to a knowledge-based economy, collaboration ratios are increasing for patent applications, R\&D activities, and new product developments [22,23]. In Finland, through motivating collaborative patents, the development of a knowledge-based economy is encouraged [24]. Patents are used to measure levels of innovation. Basically, patent counts could be used as a measure of the effect of technology-for example, innovative performance in addition to R\&D inputs, patent citations, and new product announcements in the linear process of R\&D [25]. 
Patenting figures can be used as an indicator of innovation, as a firm's propensity to patent is significantly higher in an R\&D collaboration scenario. Furthermore, these figures vary across sectors, and according to firm size [26]. Patent forward citations have become an established measure for the technological and economic value of patents in empirical innovation [27]. According to an analysis of the US pharmaceutical industry, relative patent positions (RPPs) and patent citations were positively associated with the corporate market value, while the Herfindahl-Hirschman Index (HHI) of patents was negatively associated with it, and the revealed technology advantage (RTA) was not significantly related to it [28]. In addition, according to the authors, the HHI of patents and RPP had nonlinear and monotonous positive influences on corporate performance, while patent citations had a nonlinear, U-shaped influence [29].

Meanwhile, patents are directly used in diverse studies that measure various aspects of open innovation [30,31]. Shared intellectual property rights on patents usually occur as a result of collaboration, because shared intellectual property rights on patents occur when two or more assignees are found on a single patent application, and the intellectual property rights are indeed shared between the applicants listed in a joint patent application [32]. Joint patenting results from small innovators, information R\&D collaboration, or small-sized R\&D projects [33]. The number of shared joint patent applications has increased from the 1980s, and patents with multiple applicants have mostly been concentrated in highly knowledge-intensive sectors, like biotechnology, pharmacy, information technology, or medical equipment $[32,34,35]$.

One study analyzed the open innovation of cities by the average number of joint applicants of each patent, and the ratio of jointly applied patents in target cities [36]. Another study measured the breadth of open innovation through the ratio of jointly applied patents from the total patents of a firm, and the depth of open innovation by the average number of joint applicants of each patent of a firm [37]. Another study analyzed the effect of distance on open innovation and its difference among institutions, and used the ratio of patents with joint applicants and the average number of joint applicants of each patent to measure the depth and breadth of open innovation, respectively [38]. In many studies, the co-invention index has been used to examine inter- and intranational collaborations in inventive activities, and the co-assignee index was used to examine intended inter- and intranational collaborations of the commercialization of inventive activities [39]. However, when the imitation of patents, especially in manufacturing markets, do not work well, the profits from innovation may be diverted to the owners of certain complementary assets, rather than to the developers of the intellectual property [40].

Patent diversity, which is measured by sub-IPC numbers, can be used as a predictor of regional innovativeness [41]. When multiple IPC codes exist in a single patent and those codes belong to different technology fields, we call this a case of IPC co-occurrence [42]. The distribution of main IPC codes can be used to measure intersectorial technology spillovers, such as the increase in technological value [43].

Diversifying into a greater number of different activities using the open innovation approach has been found to generate more synergistic effects than branching into a limited number of similar activities [44]. If a firm wants to obtain significant economic returns from an innovation, business strategy—particularly, as it relates to the firm's decision to integrate and collaborate-has been shown to be an important factor.

Intersectorial technology flows can be estimated from a patent's concordance with an application [45]. The technological distance between firms, on the basis of the distribution of firms' patenting activities over technology fields, has been used as another approach to measure technology transfer, and it is based on a more explicit 'technological perspective' with patents [46]. Another work measured intersectorial technology spillovers through estimates from the European and US patent office databases [43]. 


\subsection{Research Framework and Hypothesis}

In Korea, the aviation industry has been dominated by a single large company called KAI. In addition, most aviation companies in Korea, in terms of manufacturing and managing, have a strong hierarchy, centralized by KAI [3]. In other words, the aviation industry has the characteristics of low open innovation of type (A) in Figure $1[2,47,48]$.

However, the automobile industry, with various parts companies that supply complete vehicle companies in Korea and abroad, is led by three to four complete vehicle companies in accordance with the globalization of the South Korean automobile industry [49]. Thus, this type of industry has the characteristics of a loosened hierarchy and a relieved centralization with type (B) open innovation, as per Figure 1.

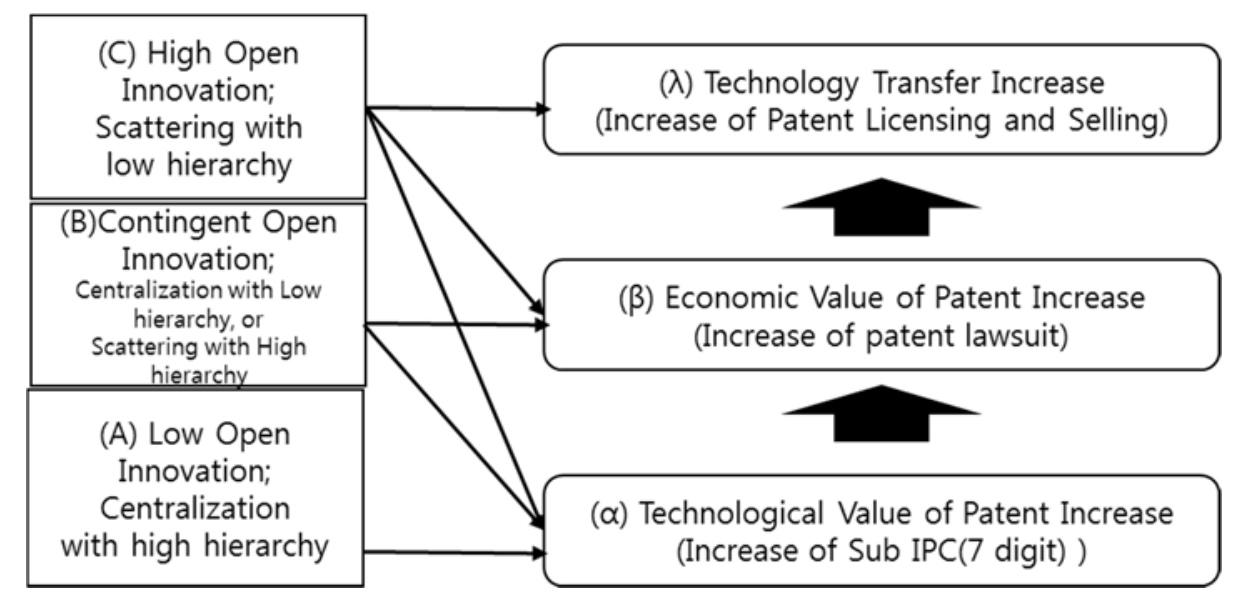

Figure 1. Research framework.

On the other hand, the Korean robotics industry does not have the centralization system of large companies, and diverse robotics companies coming from various sectors coexist together, like the Japanese intrapreneurial regime of the service robot industry, through collaborations between new firms with established large firms [8]. The Korean robotics industry has a scattered hierarchy, showing the characteristics of open innovation of type (C) in Figure 1, with many indirect polices by the Korean government [9].

Based on previous studies, we set the above research analysis framework shown in Figure 1 and tested three key hypotheses. The technological value of the patents was measured by the number of 7-digit sub-IPCs according to the literature. Second, the economic value of the patent was measured indirectly by the number of patent disputes in the literature. Third, the technology transfer of the patent was measured by the number of licenses and sales of the patents, as shown in Table 2.

Hypothesis 1 (H1). In the Korean aviation industry, which has weak characteristics of open innovation, open innovation will only have an impact on improving sub-IPCs; thus, the technical values of corporate patents will increase.

Hypothesis 2 (H2). In the Korean automobile industry, which has contingent characteristics of open innovation, open innovation will have an impact on increasing patent disputes, in addition to increasing the patent value; thus, the technical and economical values of corporate patents will be enhanced.

Hypothesis 3 (H3). The Korean robotics industry has high characteristics of open innovation; thus, open innovation will activate technology transfer, in addition to increasing the technical and economical values of corporate patents. 
According to the literature, in rare open innovation industries, such as aviation in Korea, open innovation will only increase the technological value of the firms. However, in high open innovation industries, such as robotics in Korea, open innovation will increase the transfer of technology, in addition to the increase of the technological and economic value of the firm. Therefore, in medium-level open innovation industries, such as automotives in Korea, open innovation will increase the technological and economic value of patents.

\section{Analysis and Hypothesis Tests}

\subsection{Descriptive Analysis of Patent Statistics}

The relationship between the application and registration years of patents is summarized in Figure 1, and the patents in the robotics, automobile, and aviation sectors are described in terms of their application and registration years as shown in Figure 2. In general, the patents in the three fields showed an increasing trend.

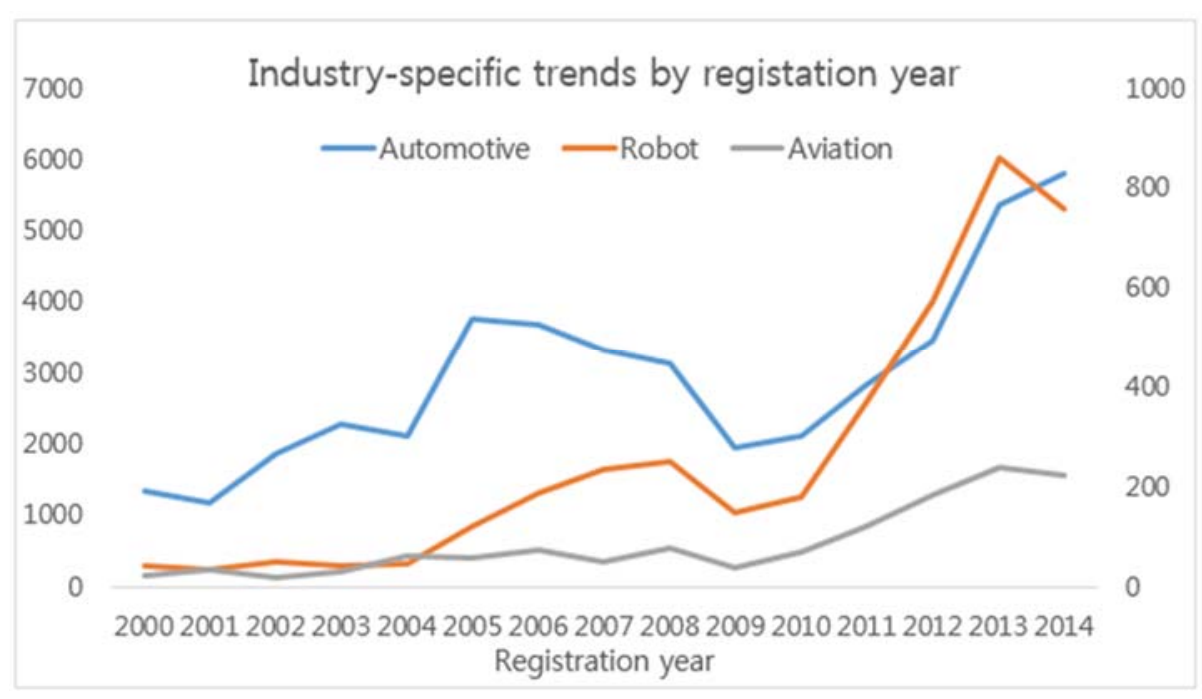

Figure 2. Trends of the three industries' patents.

\subsubsection{Ratio of Joint Patent Application}

In the joint ownership of a patent right, one invention is collaboratively applied by multiple people, and they receive its right together. In this case, it can be determined that open innovation occurs to share the technology.

In cases of patents with two or more applicants, open innovation breadth can be measured using the Ratio of open innovation $(\mathrm{ROI})=$ Number of joint applicant patents/Total number of patents. Additionally, open innovation depth can be measured by the Intensity of open innovation (IOI) = Total number of applicants/Total number of patents.

Table 3 describes the averages of the IOI and ROI of each industry based on the patent applicants. The IOI and ROI in the automobile sector were 1.37 and 24.11, respectively; those in the robotics industry were 1.49 and 27.25, respectively; and those in the aviation field were 1.41 and 23.18, respectively. However, the top three companies in the robotics industry accounted for $12.6 \%$ of all patents, while those in the automobile sector formed 37.6\%. Even in the aviation industry, the figure was $39.1 \%$, with a small number of patents. It was determined that the strongest vertical integration and centralization were in the aviation sector, but low vertical integration and centralization in the robotics industry. For the open innovation breadth, the averages of the top three firms were 4.57, 1.75 , and 1.59 in the aviation, automobile, and robotics sectors, respectively, while the entire averages were very low at $27.25,24.11$, and 23.18 , respectively. In the three industries, large companies mainly 
centered on closed innovation. Regarding the open innovation depth, the top three large companies had significantly low figures across the entire industry. This shows that large companies focused on closed innovation.

Table 3. Total measure of open innovation by patents.

\begin{tabular}{lccc}
\hline \multicolumn{1}{c}{ Division } & Automobile & Robotics & Aviation \\
\hline Total number of patents & 44,131 & 3896 & 1293 \\
\hline Top 3 firms number of patents (ratio \%) & $16,611(37.6 \%)$ & $491(12.6 \%)$ & $506(39.1 \%)$ \\
\hline Number of joint applicant patents & 3277 & 279 & 67 \\
\hline Total number of applicants & 48,060 & 4253 & 1380 \\
\hline $\begin{array}{l}\text { Average ratio of joint applied patents by each firm } \\
\rightarrow \text { Open innovation breadth }\end{array}$ & 24.11 & 27.25 & 23.18 \\
\hline $\begin{array}{l}\text { Top 3 firms } \\
\text { Open innovation breadth }\end{array}$ & 1.75 & 4.57 & 1.59 \\
\hline $\begin{array}{l}\text { Average number of applicants in each patent by each firm } \\
\rightarrow \text { Open innovation depth }\end{array}$ & 1.37 & 1.49 & 1.41 \\
\hline $\begin{array}{l}\text { Top 3 firms } \\
\text { Open innovation depth }\end{array}$ & 1.02 & 1.05 & 1.02 \\
\hline
\end{tabular}

In terms of the average of all industries, the open innovation breadth and open innovation depth, and the top three companies, the robotics industry had the most active open innovation, followed by the automobile and aviation sectors.

\subsubsection{Analysis According to the International Patent Classification}

The description of patent documents is classified according to the IPC. More classification cases mean diverse technical fields. The IPC system is composed of sections, classes, subclasses, main groups, and subgroups. As of January 2014, there were 8 sections, 129 classes, 638 subclasses, 7391 main groups, and 64,046 subgroups.

If a patent is divided into a subclass, it can be classified into a different technology. If a patent is divided into two or more subclasses, it indicates that the technologies are fused. The numbers of fused automobile, robotics, and aviation technologies were $14,285,2088$, and 686, respectively, and the automotive sector had the largest number of cases. However, the technical fusion ratios were $32.4 \%$, $53.6 \%$, and $53.1 \%$ for the automobile, robotics, and aviation sectors, respectively, and the robot and aviation industries had more fused technologies than the automotive field (Table 4).

Table 4. Sub-IPCs (International Patent Classifications) among the three sectors.

\begin{tabular}{cccc}
\hline Division & Car & Robotics & Aviation \\
\hline Total number (A) & 44,131 & 3896 & 1293 \\
Multiple case (B) & 14,285 & 2088 & 686 \\
Convergence technology ratio (B/A) (\%) & 32.4 & 53.6 & 53.1 \\
\hline
\end{tabular}

\subsubsection{Patent Disputes}

With the rapid increase in nonpracticing entities (NPEs) and the expansion of the patent business, the possibility of disputes between domestic manufacturing companies is rising. An increase in patent disputes means an increase in the economic value of the patent, according to the literature. Based on the data collected in Table 5, there were 958 patent trials in the automotive industry, 123 in the robotics industry, and 41 in the aviation industry. The automobile industry had the largest number of patent trials. However, the ratios of patent trials to patent registration cases were $2.2 \%, 3.2 \%$, and $3.2 \%$ for 
the automotive, robotics, and aviation sectors, respectively, and the automotive field had the lowest number of cases involving patent disputes.

Table 5. Patent dispute comparison among the three sectors.

\begin{tabular}{ccc}
\hline Division & Numbers & Ratio (\%) \\
\hline Car & 958 & 2.2 \\
Robotics & 123 & 3.2 \\
Aviation & 41 & 3.2 \\
\hline
\end{tabular}

\subsubsection{Number of Technology Transfer Cases}

The transfer of all patent rights accounted for $75 \%$ or more of the technology transfer cases, followed by the partial transfer of patent rights, the transfer of all patent right shares, and exclusive licensing.

The numbers of technology transfer cases for the automobile, robotics, and aviation industries were 305,426 , and 97 , respectively. The ratio of technology transfer against the number of patents was $0.7 \%$ in the automotive industry, $10.9 \%$ in the robotics sector, and $7.5 \%$ in the aviation sector, according to Table 6 . This indicates that technology transfer was not active in the automobile industry, which is based on large complete vehicle companies. In addition, technology transfer was active in the robotics sector, where each part is developed for one finished product. The Korean aviation industry has yet to mature; thus, it does not have any clear characteristics. However, technology transfers seemed to gradually increase.

Table 6. Technology transfer categories by sector.

\begin{tabular}{cccccccccc}
\hline Division & Subtotal & TT_1 & TT_2 & TT_3 & TT_4 & TT_5 & TT_6 & TT_7 & Ratio \\
\hline Car & 305 & & 13 & 4 & 43 & 217 & & 28 & 0.7 \\
Robotics & 426 & 2 & 23 & 10 & 23 & 338 & 2 & 28 & 10.9 \\
Aviation & 97 & & 5 & 7 & 7 & 69 & 1 & 8 & 7.5 \\
Total/Average & 828 & 2 & 41 & 21 & 73 & 624 & 3 & 64 & 6.4 \\
\hline
\end{tabular}

\subsection{Analysis and Hypothesis Test of Open Innovation Effects in the Aviation Industry}

Table 7 shows that the $(\mathrm{IOI} \times \mathrm{ROI})^{2}$ (that is, the single standardized value of the open innovation breadth and open innovation width), the total number of IPCs, and the total number of technology transfers had a statistically significant correlation in the aviation industry.

Table 7. Aviation industry correlation analysis.

\begin{tabular}{|c|c|c|c|c|c|c|c|c|}
\hline Category & Mean & SD & 1 & 2 & 3 & 4 & 5 & 6 \\
\hline 2. OI breadth (OIB) & 0.355 & 0.832 & $0.518^{* *}$ & & & & & \\
\hline 4. $(\mathrm{IOI} \times \mathrm{ROI})^{2}$ & 70.789 & 1455.558 & $0.807^{* *}$ & $0.505^{* *}$ & $0.994^{* *}$ & & & \\
\hline 5. Total number of technology transfers & 1.560 & 1.017 & $0.307^{* *}$ & 0.137 & $0.274^{*}$ & $0.281 *$ & & \\
\hline 6. Total number of disputes & 1.316 & 0.620 & $0.405^{*}$ & 0.295 & 0.188 & 0.186 & $-0.186^{*}$ & \\
\hline
\end{tabular}

Note: IPCs, International Patent Classifications; 7D, 7 digits; IOI, intensity of open innovation; RPO, ratio of open innovation; ${ }^{* *} p<0.01,{ }^{*} p<0.05$.

Table 8 shows that open innovation did not have a statistically significant impact on technology transfer in the aviation industry. 
Table 8. Aviation industry OI regression of the total number of technology transfers.

\begin{tabular}{ccccccc}
\hline Dependent Variables (Row) & \multicolumn{3}{c}{ Regression $\mathbf{1}$} & \multicolumn{3}{c}{ Regression 2 } \\
\cline { 2 - 7 } Independent Variables (Column) & $\mathbf{b}$ & Standard $\boldsymbol{\beta}$ & $\mathbf{t}$ & $\mathbf{b}$ & Standard $\boldsymbol{\beta}$ & $\mathbf{t}$ \\
\hline OID $\times$ OIB & 0.010 & 0.358 & 0.859 & -0.133 & -4.626 & -0.346 \\
$(\mathrm{OID} \times$ OIB) & & & & 0.001 & 4.987 & 0.373 \\
\hline $\mathrm{R}^{2}$ & & 0.128 & & & 0.158 \\
$\mathrm{~F}$ & & 0.737 & & & 0.375 \\
\hline
\end{tabular}

Table 9 shows that open innovation did not have a statistically significant effect on the number of patent disputes, in other words, there was no change to the improvement of the economic values of patents in the aviation industry.

Table 9. Aviation industry OI regression of the total number of patent disputes.

\begin{tabular}{ccccccc}
\hline Dependent Variables (Row) & \multicolumn{3}{c}{ Regression $\mathbf{1}$} & \multicolumn{3}{c}{ Regression 2 } \\
\cline { 2 - 7 } Independent Variables (Column) & $\mathbf{b}$ & Standard $\boldsymbol{\beta}$ & $\mathbf{t}$ & $\mathbf{b}$ & Standard $\boldsymbol{\beta}$ & $\mathbf{t}$ \\
\hline OID $\times$ OIB & 0.003 & 0.226 & 0.518 & -0.151 & -12.623 & -0.998 \\
$(\mathrm{OID} \times$ OIB) & & & & 0.001 & 12.856 & 1.016 \\
\hline $\mathrm{R}^{2}$ & & 0.051 & & & 0.246 \\
$\mathrm{~F}$ & & 0.269 & & & 0.651 \\
\hline
\end{tabular}

Table 10 shows that open innovation had a statistically significant impact on the increase in the number of 7-digit IPCs in patents, in other words, the enhancement of the technical values of patents in the aviation industry was affected.

Table 10. Aviation industry OI regression of the total number of IPCs (7D).

\begin{tabular}{ccccccc}
\hline Dependent Variables (Row) & \multicolumn{3}{c}{ Regression $\mathbf{1}$} & \multicolumn{3}{c}{ Regression 2 } \\
\cline { 2 - 7 } Independent Variables (Column) & $\mathbf{b}$ & Standard $\boldsymbol{\beta}$ & $\mathbf{t}$ & $\mathbf{b}$ & Standard $\boldsymbol{\beta}$ & $\mathbf{t}$ \\
\hline OID $\times$ OIB & 2.703 & $0.782^{*}$ & 2.803 & -48.064 & -13.900 & -2.600 \\
$(\mathrm{OID} \times$ OIB) & & & & 0.292 & -14.691 & 2.748 \\
\hline $\mathrm{R}^{2}$ & & 0.611 & & & 0.865 \\
$\mathrm{~F}$ & & $7.858^{*}$ & & \multicolumn{3}{c}{$12.852^{*}$} \\
\hline
\end{tabular}

Note: IPCs, International Patent Classifications; 7D, 7 digits; ${ }^{*} p<0.05$.

According to Tables 7-10, Hypothesis 1 is accepted. Therefore, in the Korean aviation industry, open innovation only had an impact on improving the sub-IPCs, that is, there was an increase of the technical values of corporate patents.

\subsection{Analysis and Hypothesis Test of Open Innovation Effects in the Automobile Industry}

Table 11 shows the $(\mathrm{IOI} \times \mathrm{ROI})^{2}$ (that is, the single standardized values of the open innovation breadth and open innovation width), the total number of IPCs, and the total number of patent disputes had a statistically significant correlation in the automobile sector. 
Table 11. Automobile industry correlation analysis.

\begin{tabular}{lcccccccc}
\hline \multicolumn{1}{c}{ Category } & Mean & SD & $\mathbf{1}$ & $\mathbf{2}$ & $\mathbf{3}$ & $\mathbf{4}$ & $\mathbf{5}$ & $\mathbf{6}$ \\
\hline 1. OI depth (OID) & 8.639 & 170.432 & - & & & & & \\
2. OI breadth (OIB) & 0.676 & 7.018 & $0.923^{*}$ & & & & & \\
3. OID $\times$ OIB & 0.922 & 72.278 & $0.947^{*}$ & $0.931^{*}$ & & & & \\
4. (OID $\times$ OIB) & 5224.173 & 4.315 & $0.944^{*}$ & $0.927^{*}$ & $1.000^{*}$ & & & \\
5. Total number of technology transfers & 1.905 & 3.570 & -0.570 & 0.066 & -0.660 & -0.660 & & \\
6. Total number of disputes & 2.339 & 4.524 & $0.703^{*}$ & $0.692^{*}$ & $0.612^{*}$ & $0.605^{*}$ & $-0.605^{*}$ & \\
7. Total number of IPCs (7D) & 13.330 & 267.679 & $0.995^{*}$ & $0.936^{*}$ & $0.936^{*}$ & $0.955^{*}$ & $-0.955^{*}$ & $0.709^{*}$ \\
\hline
\end{tabular}

Note: IPCs, International Patent Classifications; 7D, 7 digits; * $p<0.01$.

Table 12 shows that open innovation had a statistically significant impact on technology transfer in the automobile industry.

Table 12. Automobile industry OI regression of the total number of technology transfers.

\begin{tabular}{ccccccc}
\hline \multirow{2}{*}{$\begin{array}{c}\text { Dependent Variables (Row) } \\
\text { Independent Variables (Column) }\end{array}$} & $\mathbf{b}$ & Standard $\boldsymbol{\beta}$ & $\mathbf{t}$ & $\mathbf{b}$ & Standard $\boldsymbol{\beta}$ & $\mathbf{t}$ \\
\cline { 2 - 7 } & -0.001 & -0.080 & -0.414 & -0.009 & -1.151 & -0.065 \\
OID $\times$ OIB & & & & $1.407 \times 10^{-6}$ & 1.072 & 0.061 \\
$(\mathrm{OID} \times$ OIB) & & & & & & 0.006 \\
\\
$\mathrm{R}^{2}$ & & 0.006 & & & 0.085 \\
$\mathrm{~F}$ & & 0.172 & & & \\
\hline
\end{tabular}

Table 13 shows that open innovation had a statistically significant effect on the number of patent disputes, in other words, the improvement of the economic values of patents in the automobile industry was affected.

Table 13. Automobile industry OI regression to the total number of patent disputes.

\begin{tabular}{|c|c|c|c|c|c|c|}
\hline \multirow{2}{*}{$\begin{array}{c}\text { Dependent Variables (Row) } \\
\text { Independent Variables (Column) }\end{array}$} & \multicolumn{3}{|c|}{ Regression 1} & \multicolumn{3}{|c|}{ Regression 2} \\
\hline & b & Standard $\beta$ & $\mathbf{t}$ & b & Standard $\beta$ & $\mathbf{t}$ \\
\hline $\begin{array}{c}\mathrm{OID} \times \mathrm{OIB} \\
(\mathrm{OID} \times \mathrm{OIB})^{2}\end{array}$ & 0.011 & $0.943 *$ & 14.707 & $\begin{array}{c}0.278 \\
-4.482 \times 10^{-5}\end{array}$ & $\begin{array}{c}24.864 * \\
-23.922 *\end{array}$ & $\begin{array}{c}6.976 \\
-6.712\end{array}$ \\
\hline $\mathrm{R}^{2}$ & & 0.889 & & & 0.959 & \\
\hline $\mathrm{F}$ & & 216.296 * & & & $307.116^{*}$ & \\
\hline
\end{tabular}

Table 14 shows that open innovation had a statistically significant impact on the increase in the number of 7-digit IPCs in patents, in other words, the enhancement of the technical values of patents in the automobile industry was affected.

Table 14. Automobile OI regression of the total number of IPCs (7D).

\begin{tabular}{ccccccc}
\hline Dependent Variables (Row) & \multicolumn{3}{c}{ Regression $\mathbf{1}$} & \multicolumn{3}{c}{ Regression 2 } \\
\cline { 2 - 7 } Independent Variables (Column) & $\mathbf{b}$ & Standard $\boldsymbol{\beta}$ & $\mathbf{t}$ & $\mathbf{b}$ & Standard $\boldsymbol{\beta}$ & $\mathbf{t}$ \\
\hline OID $\times$ OIB & 3.508 & $0.989 *$ & 34.277 & 50.655 & $14.277^{*}$ & 29.448 \\
$(\mathrm{OID} \times \mathrm{OIB})^{2}$ & & & & -0.008 & $-13.289 *$ & -27.411 \\
\hline $\mathrm{R}^{2}$ & \multicolumn{3}{c}{0.978} & & 0.999 \\
$\mathrm{~F}$ & \multicolumn{3}{c}{$1174.897^{*}$} & & \multicolumn{3}{c}{$17288.739 *$} \\
\hline
\end{tabular}

Note: IPCs, International Patent Classifications; 7D, 7 digits; ${ }^{*} p<0.01$.

According to Tables 11-14, Hypothesis 2 is accepted. Therefore, in the Korean automobile industry, open innovation has an impact on increasing patent disputes, that is, the economic value of the patents increased, in addition to the increase in the technological value of the patent. 


\subsection{Analysis and Hypothesis Test of Open Innovation Effects in the Robot Industry}

Table 15 shows the $(\mathrm{IOI} \times \mathrm{ROI})^{2}$ (that is, the single standardized values of the open innovation breadth and open innovation width), the total number of IPCs, the total number of patent disputes, and the total number of technology transfers had a statistically significant correlation in the robotics sector.

Table 15. Robotics industry correlation analysis.

\begin{tabular}{lcccccccc}
\hline \multicolumn{1}{c}{ Category } & Mean & SD & $\mathbf{1}$ & $\mathbf{2}$ & $\mathbf{3}$ & $\mathbf{4}$ & $\mathbf{5}$ & $\mathbf{6}$ \\
\hline 1. OI depth (OID) & 5.286 & 13.472 & - & & & & & \\
2. OI breadth (OIB) & 0.567 & 1.294 & $0.456^{*}$ & & & & & \\
3. OID $\times$ OIB & 0.456 & 4.365 & $0.523^{*}$ & $0.603^{*}$ & & & & \\
4. (OID $\times$ OIB) & 19.242 & 488.277 & $0.389^{*}$ & $0.384^{*}$ & $0.917^{*}$ & & & \\
5. Total number of technology transfers & 2.071 & 3.156 & $0.641^{*}$ & $0.288^{*}$ & $0.300^{*}$ & $0.191^{*}$ & & \\
6. Total number of disputes & 1.677 & 1.533 & $0.591^{*}$ & $0.228^{* *}$ & $0.470^{*}$ & $0.509^{*}$ & 0.397 & \\
7. Total number of IPCs (7D) & 9.364 & 30.489 & $0.956^{*}$ & $0.313^{*}$ & $0.415^{*}$ & $0.330^{*}$ & $0.551^{*}$ & $0.483^{*}$ \\
\hline
\end{tabular}

Note: IPCs, International Patent Classifications; 7D, 7 digits; ${ }^{*} p<0.01,{ }^{* *} p<0.05$.

Table 16 shows that open innovation had a statistically significant impact on technology transfer in the robotics industry.

Table 16. Robotics industry OI regression of the total number of technology transfers.

\begin{tabular}{|c|c|c|c|c|c|c|}
\hline \multirow{2}{*}{$\begin{array}{c}\text { Dependent Variables (Row) } \\
\text { Independent Variables (Column) }\end{array}$} & \multicolumn{3}{|c|}{ Regression 1} & \multicolumn{3}{|c|}{ Regression 2} \\
\hline & $\mathbf{b}$ & Standard $\beta$ & $\mathbf{t}$ & $\mathbf{b}$ & Standard $\beta$ & $\mathbf{t}$ \\
\hline $\mathrm{OID} \times \mathrm{OIB}$ & 0.404 & 0.537 * & 2.846 & 1.022 & 1.359 & 2.039 \\
\hline$(\mathrm{OID} \times \mathrm{OIB})^{2}$ & & & & -0.029 & -0.856 & 1.284 \\
\hline$R^{2}$ & \multicolumn{3}{|c|}{0.288} & \multicolumn{3}{|c|}{0.345} \\
\hline $\mathrm{F}$ & \multicolumn{3}{|c|}{$8.098 *$} & \multicolumn{3}{|c|}{$5.005 *$} \\
\hline
\end{tabular}

Table 17 shows that open innovation had a statistically significant effect on the number of patent disputes, in other words, the improvement in the economic values of patents in the robotics industry was affected.

Table 17. Robotics industry OI regression of the total number of patent disputes.

\begin{tabular}{ccccccc}
\hline Dependent Variables (Row) & \multicolumn{3}{c}{ Regression $\mathbf{1}$} & \multicolumn{3}{c}{ Regression 2 } \\
\cline { 2 - 7 } Independent Variables (Column) & $\mathbf{b}$ & Standard $\boldsymbol{\beta}$ & $\mathbf{t}$ & $\mathbf{b}$ & Standard $\boldsymbol{\beta}$ & $\mathbf{t}$ \\
\hline OID $\times$ OIB & 0.184 & $0.702 *$ & 4.407 & 0.248 & 0.948 & 1.626 \\
$\left(\mathrm{OID} \times\right.$ OIB) ${ }^{2}$ & & & & -0.003 & -0.257 & -0.440 \\
\hline $\mathrm{R}^{2}$ & & 0.493 & & 0.498 \\
$\mathrm{~F}$ & $19.425^{*}$ & & & $9.418^{*}$ \\
\hline
\end{tabular}

Table 18 shows that open innovation had a statistically significant impact on the increase in the number of 7-digit IPCs in patents, in other words, the enhancement of the technical values of patents in the robotics industry was affected. 
Table 18. Robotics industry OI regression of the total number of IPCs (7D).

\begin{tabular}{ccccccc}
\hline Dependent Variables (Row) & \multicolumn{3}{c}{ Regression $\mathbf{1}$} & \multicolumn{3}{c}{ Regression 2 } \\
\cline { 2 - 7 } Independent Variables (Column) & $\mathbf{b}$ & Standard $\boldsymbol{\beta}$ & $\mathbf{t}$ & $\mathbf{b}$ & Standard $\boldsymbol{\beta}$ & $\mathbf{t}$ \\
\hline OID $\times$ OIB & 7.747 & $0.740^{*}$ & 4.913 & 7.734 & 0.738 & 1.332 \\
$(\mathrm{OID} \times$ OIB) & & & & 0.001 & 0.001 & 0.002 \\
\hline $\mathrm{R}^{2}$ & & 0.547 & & 0.547 \\
$\mathrm{~F}$ & \multicolumn{3}{c}{$24.141^{*}$} \\
\end{tabular}

Note: IPCs, International Patent Classifications; 7D, 7 digits; * $p<0.01$.

According to Tables 15-18, Hypothesis 3 is accepted. Therefore, in the Korean robotics industry, open innovation activated technology transfer, in addition to increasing the technical and economic value of corporate patents.

\section{Discussion}

\subsection{High Concentration of Top Companies in Korea Is Opposite to Their Low Open Innovation}

According to Table 3, the top three companies in the Korean robotics industry accounted for $12.6 \%$ of all patent applications, while those in the automobile and aviation sectors accounted for $37.6 \%$ and $39.1 \%$, respectively. The open innovation breadths of the robotics, automobile, and aviation sectors were $4.57,1.75$, and 1.59 , respectively, a trend that is exactly opposite to their industrial concentration. Their open innovation depths were 1.49, 1.37, and 1.41, respectively. An industry with a low concentration has, on average, a significant amount of large open innovation. That is, when there is a high concentration of top companies in an industry, collaboration with outside groups for developing new technologies significantly decreases.

\subsection{Leading Companies in Major Industries of Korea Are Still Focusing on Closed Innovation}

The top three firms pursued significantly low open innovation, considering the industry average. That is, the companies leading the industries promoted a closed innovation strategy. The averages of the top three companies in the robotics, automobile, and aviation sectors in terms of the open innovation breadth were $4.57,1.75$, and 1.59 , respectively, which are much lower than the industry averages of $27.25,24.11$, and 23.18 , respectively. The averages of their open innovation depths were $1.05,1.02$, and 1.02, respectively, which are also significantly lower than the averages of 1.49, 1.37, and 1.41, respectively. This shows that large Korean companies stressed a closed innovation strategy and went against the global open innovation trend that is being further strengthened under the Fourth Industrial Revolution as industries grow, even though the situation may be different depending on the industrial vertical integration status.

\subsection{The Possibility of Commercializing Patents Increases through Coapplying Them}

In the case of an industry or company with low open innovation, like the aviation sector, or, in other words, an industry or company with low joint patent application, open innovation has limited effects on the enhancement of the technical values of patents. However, in the case of an industry or company with high open innovation, like the robotics industry (that is, an industry or company with high joint patent applications), open innovation effects lead to improvements in the technical and economic values of the patents, and, furthermore, significantly increases the possibility of patent commercialization through patent transfer.

Thus, it is determined that a strategy where all related companies join a patent application from the beginning and develop a technology together increases the possibility of commercializing that technology. In addition, the activation of joint patent applications through collaboration between colleges and companies during patent application and technology development has a 
much higher possibility of commercializing the technology than technology transfer to a company after the technology development and patent application by a college. The reason is that the collaboration between related organizations/companies and colleges/research institutes during technology development and patent application, rather than sharing complete technology or transferring patents, increases diverse market values in various aspects of the patent, resulting in a greater possibility of finally commercializing the technology.

\section{Conclusions}

\subsection{Implication}

This study analyzed the impact of open innovation on the improvement of the technical and economic values of patents and the technology transfers in the top three sectors of Korea: automobile, aviation, and robotics. First, this research defined the open innovation level as the occurrence of companies jointly applied for a patent, and how many subjects were involved in a patent application, and then measured the open innovation level with practical and objective methods. The open innovation index for the three industries of Korea had a statistically significant correlation with other patent indexes. One of the important results of this study was the verification of the validity and value of the open innovation measurement index.

Second, this research presumed the technical value of a patent as the 7-digit sub-IPC of the patent. In the three industries, the open innovation level and the sub-IPC quantity were statistically significant. Thus, it was determined that the method is suitable as a measurement index for the technical values of patents.

Third, this study measured the economic values of patents with corporate patent dispute counts. The recognition of economic values of the patents was characterized as being fairly related to their economic reality. Through this index, it was verified that, in the Korean robotics and automobile industries that have relatively low concentrations, open innovation had a statistically significant impact on patent disputes.

Fourth, this research measured whether the effect of open innovation had a statistically significant effect on the time spent before filing a patent. Another important result of this study was from the direct analysis of the statistical relationship between the open innovation level of joint patent applications and the patent technology transfers of a company. In other words, this study directly measured that joint patent application had a statistically significant impact on corporate technology transfer in the robotics sector, which has high open innovation in joint patent applications and low industry dominance of the top three companies, whose patent ratio was around $10 \%$.

\subsection{Limitations and Future Research Agenda}

This study statistically established the relations between the open innovation level of joint patent applications, technical and economic values of patents, and technology transfer. First, various situations of joint patent application of companies needed to be analyzed in depth. A follow-up study to practically analyze the characteristics of joint patent application in each industry should be conducted by analyzing the joint patent application cases of each sector.

Second, there is a need to establish the practical impact of joint patent application on the improvement of the technical and economic values of the patents by analyzing cases in depth. To identify the how joint patent applications enhance the technical and economic values of patents in different sectors, cases should be analyzed to compare those in industries.

Third, through in-depth case studies of joint patent application leading to patent transfer and commercialization, the conditions, determinants, and structures enabling this scenario should be determined. In addition, due to the variation in differentiation status and descriptions between industries in terms of the conditions, determinants, and structures, each industry needs to be compared and analyzed with respect to joint patent applications leading to patent transfer and commercialization. 
Author Contributions: J.J.Y. did conceptualization, Formal analysis, and Writing-Original draft prepation. E.J. did Data Curation, and Supervision. Y.L. did validation. K.K. did formal analysis together with J.J.Y.

Acknowledgments: This work was supported by the Fire Fighting Safety \& 119 Rescue Technology Research and Development Program which was funded to DGIST by the Ministry of Public Safety and Security of Korea (NEMA-NextGeneration-2014-58-2).

Conflicts of Interest: The authors declare no conflict of interest.

\section{References}

1. Park, H.S. Technology convergence, open innovation, and dynamic economy. J. Open Innov. Technol. Mark. Complex. 2017, 13, 24. [CrossRef]

2. Bowen, J.T. Global production networks, the developmental state and the articulation of Asia Pacific economies in the commercial aircraft industry. Asia Pac. Viewp. 2007, 48, 312-329. [CrossRef]

3. Park, Y.; Lee, S.; Lee, S. Patent analysis for promoting technology transfer in multi-technology industries: The Korean aerospace industry case. J. Technol. Transf. 2012, 37, 355-374. [CrossRef]

4. Dyer, J.H.; Chu, W. The role of trustworthiness in reducing transaction costs and improving performance: Empirical evidence from the United States, Japan, and Korea. Organ. Sci. 2003, 14, 57-68. [CrossRef]

5. Park, S.; Hartley, J.L.; Wilson, D. Quality management practices and their relationship to buyer's supplier ratings: A study in the Korean automotive industry. J. Oper. Manag. 2001, 19, 695-712. [CrossRef]

6. Yun, J.J.; Won, D.; Jeong, E.; Park, K.; Yang, J.; Park, J. The relationship between technology, business model, and market in autonomous car and intelligent robot industries. Technol. Forecast. Soc. 2016, 103, 142-155. [CrossRef]

7. Kim, Y.-Z.; Lee, K. Sectoral innovation system and a technological catch-up: The case of the capital goods industry in Korea. Glob. Econ. Rev. 2008, 37, 135-155. [CrossRef]

8. Lechevalier, S.; Nishimura, J.; Storz, C. Diversity in patterns of industry evolution: How an intrapreneurial regime contributed to the emergence of the service robot industry. Res. Policy 2014, 43, 1716-1729. [CrossRef]

9. Sohn, S.Y.; Kim, M.J. Strategies for revitalization for intelligent robot industry in Korea based on structural equation model. Ind. Robot 2010, 37, 97-105. [CrossRef]

10. Lundvall, B.- $\AA$. Innovation studies: A personal interpretation of the state of the art. In Innovation Studies: Evolution and Future Challenges; Fagerberg, J., Martin, B., Andersen, E.S., Eds.; Oxford University Press: New York, NY, USA, 2013; pp. 21-70. ISBN 978-0-19-968634-6.

11. Chesbrough, H.W. Open Innovation: The New Imperative for Creating and Profiting from Technology; Harvard Business Press: Brighton, MA, USA, 2003; pp. 34-36, ISBN-10: 1422102831.

12. Mention, A.-L.; Asikainen, A.-L. Measuring the impact of inbound open innovation practices on performance. In Services Open Innovation Research, Management and Practice; Tidd, J., Ed.; World Scientific: Singapore, 2014; Volume 23, pp. 237-265. ISBN 978-1-78326-280-9.

13. Leydesdorff, L.; Ivanova, I. "Open innovation" and "triple helix" models of innovation: Can synergy in innovation systems be measured? J. Open Innov. Technol. Mark. Complex. 2016, 2, 11. [CrossRef]

14. Chesbrough, H.W.; Teece, D.J. Organizing for Innovation: When Is Virtual Virtuous? The Transfer and Licensing of Know-How and Intellectual Property: Understanding the Multinational Enterprise in the Modern World; World Scientific: Singapore, 2008; pp. 335-341. ISBN 978-981-256-849-6.

15. Yun, J.J.; Won, D.; Park, K. Dynamics from open innovation to evolutionary change. J. Open Innov. Technol. Mark. Complex. 2016, 2, 7. [CrossRef]

16. Romer, P. Foreword. In Patents, Citations, and Innovations: A Window on the Knowledge Economy; Trajtenberg, M., Jaffe, A.B., Eds.; MIT Press: Cambridge, UK, 2002; pp. 9-11. ISBN 9780262100953.

17. Sneed, K.A.; Johnson, D.K. Selling ideas: The determinants of patent value in an auction environment. $R$ D Manag. 2009, 39, 87-94. [CrossRef]

18. Agarwal, R.; Ganco, M.; Ziedonis, R.H. Reputations for toughness in patent enforcement: Implications for knowledge spillovers via inventor mobility. Strateg. Manag. J. 2009, 30, 1349-1374. [CrossRef]

19. Reitzig, M.; Wagner, S. The hidden costs of outsourcing: Evidence from patent data. Strateg. Manag. J. 2010, 31, 1183-1201. [CrossRef]

20. Aoki, R.; Schiff, A. Promoting access to intellectual property: Patent pools, copyright collectives, and clearinghouses. R D Manag. 2008, 38, 189-204. [CrossRef] 
21. Joshi, A.M.; Nerkar, A. When do strategic alliances inhibit innovation by firms? Evidence from patent pools in the global optical disc industry. Strateg. Manag. J. 2011, 32, 1139-1160. [CrossRef]

22. Hagedoorn, J.; Cloodt, M. Measuring innovative performance: Is there an advantage in using multiple indicators? Res. Policy 2003, 32, 1365-1379. [CrossRef]

23. Yun, J.J.; Jeong, E.; Park, J. Network analysis of open innovation. Sustainability 2016, 8, 729. [CrossRef]

24. Galabova, L.P. Developing a knowledge-based economy through innovation policy: The cases of Bulgaria, Finland and Scotland. Sci. Public Policy 2012, 39, 802-814. [CrossRef]

25. Johnstone, N.; Haščič, I.; Popp, D. Renewable energy policies and technological innovation: Evidence based on patent counts. Environ. Resour. Econ. 2010, 45, 133-155. [CrossRef]

26. Brouwer, E.; Kleinknecht, A. Innovative output, and a firm's propensity to patent: An exploration of CIS micro data. Res. Policy 1999, 28, 615-624. [CrossRef]

27. Czarnitzki, D.; Hussinger, K.; Leten, B. The Market Value of Blocking Patent Citations; Paper No. 11-021; ZEW Discussion: Mannheim, Germany, 2011. [CrossRef]

28. Chen, Y.-S.; Chang, K.-C. The nonlinear nature of the relationships between the patent traits and corporate performance. Scientometrics 2010, 82, 201-210. [CrossRef]

29. Chen, Y.-S.; Chang, K.-C. The relationship between a firm's patent quality and its market value-The case of US pharmaceutical industry. Technol. Forecast. Soc. Chang. 2010, 77, 20-33. [CrossRef]

30. Gupta, A.K.; Dey, A.R.; Shinde, C.; Mahanta, H.; Patel, C.; Patel, R.; Sahay, N.; Sahu, B.; Vivekanandan, P.; Verma, S.; et al. Theory of open inclusive innovation for reciprocal, responsive and respectful outcomes: Coping creatively with climatic and institutional risks. J. Open Innov. Technol. Mark. Complex. 2016, 2, 16. [CrossRef]

31. Svirina, A.; Zabbarova, A.; Oganisjana, K. Implementing open innovation concept in social business. J. Open Innov. Technol. Mark. Complex. 2016, 2, 20. [CrossRef]

32. Fier, H.; Pyka, A. Is it worth all the trouble? An assessment of the economic value of firm patent applications with shared intellectual property rights in the biotechnology industry Technology Transfer in a Global Economy. In Technology Transfer in a Global Economy; Audretsch, D., Lehmann, E., Link, A., Sarnecker, A., Eds.; Springer: New York, NY, USA, 2012; pp. 123-142, ISBN 978-1-4614-6102-9.

33. Hicks, D.; Narin, F. Strategic Research Alliances and 360 Degree Bibliometric Indicators. In Strategic Research Partnerships-Proceedings from a National Science Foundation Workshop; Janowski, J.E., Link, A.N., Vonortas, N.S., Eds.; National Science Foundation: Washington, DC, USA, 2001.

34. Hagedoorn, J. Sharing intellectual property rights-An exploratory study of joint patenting amongst companies. Ind. Corp. Chang. 2003, 12, 1035-1050. [CrossRef]

35. Hagedoorn, J.; Kranenburg, H.V.; Osborn, R.N. Joint patenting amongst companies-exploring the effects of inter-firm R\&D partnering and experience. Manag. Decis. Econ. 2003, 24, 71-84.

36. Yun, J.J.; Jeong, E.; Yang, J. Open innovation of knowledge cities. J. Open Innov. Technol. Mark. Complex. 2015, 1, 16. [CrossRef]

37. Yun, J.J.; Avvari, M.V.; Jeong, E.-S.; Lim, D.-W. Introduction of an objective model to measure open innovation and its application to the information technology convergence sector. Int. J. Technol. Policy Manag. 2014, 14, 383-400. [CrossRef]

38. Yun, J.J.; Jeong, E.; Lee, C.; Park, J.; Zhao, X. Effect of distance on open innovation: Differences among institutions according to patent citation and reference. Sustainability 2017, 9, 1478. [CrossRef]

39. Ma, Z.; Lee, Y. Patent application and technological collaboration in inventive activities: 1980-2005. Technovation 2008, 28, 379-390. [CrossRef]

40. Teece, D.J. Profiting from technological innovation: Implications for integration, collaboration, licensing and public policy. Res. Policy 1986, 15, 285-305. [CrossRef]

41. Ejermo, O. Patent Diversity as a Predictor of Regional Innovativeness in Sweden; Università Commerciale Luigi Bocconi: Milan, Italy, 2003.

42. Suzuki, J.; Kodama, F. Technological diversity of persistent innovators in Japan: Two case studies of large Japanese firms. Res. Policy 2004, 33, 531-549. [CrossRef]

43. Verspagen, B. Measuring intersectoral technology spillovers: Estimates from the European and US patent office databases. Econ. Syst. Res. 1997, 9, 47-65. [CrossRef] 
44. De Silva, L.R.; Uyarra, E.; Oakey, R. Academic entrepreneurship in a resource-constrained environment: Diversification and synergistic effects. In Technology Transfer in a Global Economy; Audretsch, D., Lehmann, E., Link, A., Starnecker, A., Eds.; Springer: Boston, MA, USA, 2012; Volume 28, pp. 73-97, ISBN 978-1-4614-6102-9.

45. Putnam, J.; Evenson, R.E. Inter-Sectoral Technology Flows: Estimates from a Patent Concordance with an Application to Italy; Yale University: New Haven, CT, USA, 1994.

46. Jaife, A. Technological Opportunity and spillovers of R\&D: Evidence from firms' patents, profits, and market value. Am. Econ. Rev. 1986, 76, 984-1001.

47. Lee, J.J.; Yoon, H. A comparative study of technological learning and organizational capability development in complex products systems: Distinctive paths of three latecomers in military aircraft industry. Res. Policy 2015, 44, 1296-1313. [CrossRef]

48. Park, H.; Kang, M.J.; Son, S. Factors affecting quality and performance-A case study of Korean aircraft maintenance unit. Total Qual. Manag. Bus. 2012, 23, 197-219. [CrossRef]

49. Park, B.G. Politics of scale and the globalization of the South Korean automobile industry. Econ. Geogr. 2003, 79, 173-194. [CrossRef]

(C) 2018 by the authors. Licensee MDPI, Basel, Switzerland. This article is an open access article distributed under the terms and conditions of the Creative Commons Attribution (CC BY) license (http:/ / creativecommons.org/licenses/by/4.0/). 